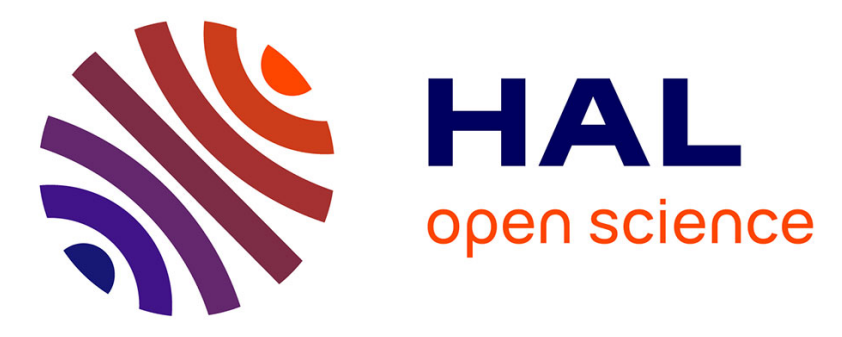

\title{
Review of Actinide Decorporation with Chelating Agents
}

Éric Ansoborlo, Badia Amekraz, Christophe Moulin, Valérie Moulin, Frédéric Taran, Théodorine Bailly, Ramon Burgada, Marie-Hélène Hengé-Napoli, Aurélie Jeanson, Christophe den Auwer, et al.

\section{To cite this version:}

Éric Ansoborlo, Badia Amekraz, Christophe Moulin, Valérie Moulin, Frédéric Taran, et al.. Review of Actinide Decorporation with Chelating Agents. Comptes Rendus. Chimie, 2007, 10 (10-11), pp.10101019. 10.1016/j.crci.2007.01.015 . cea-01273033

\section{HAL Id: cea-01273033 https://hal-cea.archives-ouvertes.fr/cea-01273033}

Submitted on 11 Feb 2016

HAL is a multi-disciplinary open access archive for the deposit and dissemination of scientific research documents, whether they are published or not. The documents may come from teaching and research institutions in France or abroad, or from public or private research centers.
L'archive ouverte pluridisciplinaire HAL, est destinée au dépôt et à la diffusion de documents scientifiques de niveau recherche, publiés ou non, émanant des établissements d'enseignement et de recherche français ou étrangers, des laboratoires publics ou privés. 
Account / Revue

\title{
Review of actinide decorporation with chelating agents
}

\author{
Éric Ansoborlo ${ }^{\mathrm{a} * *}$, Badia Amekraz $^{\mathrm{b}}$, Christophe Moulin ${ }^{\mathrm{b}}$, Valérie Moulin ${ }^{\mathrm{c}}$, \\ Frédéric Taran ${ }^{\mathrm{d}}$, Théodorine Bailly ${ }^{\mathrm{e}}$, Ramon Burgada ${ }^{\mathrm{e}}$, \\ Marie-Hélène Hengé-Napoli ${ }^{\mathrm{f}}$, Aurélie Jeanson ${ }^{\mathrm{g}}$, \\ Christophe Den Auwer ${ }^{\mathrm{g}}$, Lucie Bonin ${ }^{\mathrm{g}}$, Philippe Moisy ${ }^{\mathrm{g}}$ \\ ${ }^{a}$ CEA/DEN/DRCP/CETAMA, VRH-Marcoule, BP 17171, 30207 Bagnols-sur-Cèze, France \\ ${ }^{\mathrm{b}} C E A / D E N / D P C / S E C R$, Saclay, 91191 Gif-sur-Yvette, France \\ ${ }^{\mathrm{c}} C E A / D E N / D D I N / M R$, Saclay, 91191 Gif-sur-Yvette, France \\ ${ }^{\mathrm{d}}$ CEA/DSVIDBJC/SMMCB, 91191 Gif-sur-Yvette, France \\ ${ }^{\mathrm{e}}$ CNRS/LCSB/UMR 7033, 93017 Bobigny, France \\ ${ }^{\mathrm{f}}$ CEA/INSTN, Marcoule, BP 17171, 30207 Bagnols-sur-Cèze, France \\ ${ }^{\mathrm{g}}$ CEA/DEN/DRCP/SCPS, VRH-Marcoule, BP 17171, 30207 Bagnols-sur-Cèze, France
}

Received 16 November 2006; accepted after revision 31 January 2007

\begin{abstract}
In case of accidental release of radionuclides in a nuclear facility or in the environment, internal contamination (inhalation, ingestion or wound) with actinides represents a severe health risk to human beings. It is therefore important to provide effective chelation therapy or decorporation to reduce acute radiation damage, chemical toxicity, and late radiation effects.

Speciation governs bioavailability and toxicity of elements and it is a prerequisite tool for the design and success of new ligands or chelating agents. The purpose of this review is to present the state-of-the-art of actinide decorporation within biological media, to recall briefly actinide metabolism, to list the basic constraints of actinide-ligand for development, to describe main tools developed and used for decorporation studies, to review mainly the chelating agents tested for actinides, and finally to conclude on the future trends in this field. To cite this article: É. Ansoborlo et al., C. R. Chimie X 33 (2007).
\end{abstract}

(C) 2007 Académie des sciences. Published by Elsevier Masson SAS. All rights reserved.

\section{Résumé}

En cas de rejet accidentel de radionucléides dans une installation nucléaire ou dans l'environnement, il existe un risque de contamination interne (inhalation, ingestion ou blessure) pour l'homme et il est important de pouvoir fournir un traitement thérapeutique par des agents chélatants ou décorporation permettant de réduire la dose, la toxicité chimique et les effets retardés des radiations.

La spéciation domine la biodisponibilité et la toxicité des éléments et représente un outil indispensable pour la conception et l'efficacité de nouveaux ligands ou chélatants. Le but de cet article est de présenter l'état de l'art sur la décorporation des actinides en milieu biologique, de rappeler les grandes lignes du métabolisme des actinides, de lister les contraintes indispensables actinide-

\footnotetext{
* Corresponding author.

E-mail address: eric.ansoborlo@cea.fr (É. Ansoborlo).
} 
ligands pour la décorporation, de décrire succinctement les principaux outils expérimentaux ou analytiques utilisés, de passer en revue les principaux ligands testés pour les actinides et de présenter les orientations du futur dans ce domaine. Pour citer cet article : É. Ansoborlo et al., C. R. Chimie X 33 (2007).

(C) 2007 Académie des sciences. Published by Elsevier Masson SAS. All rights reserved.

Keywords: Actinide biochemistry; Actinide chemistry; Speciation; Decorporation; Chelating agents

Mots-clés : Biochimie des actinides ; Chimie des actinides ; Spéciation ; Décorporation ; Agents chélatants

\section{Introduction}

In case of accidental release of actinides (An: Th, U, $\mathrm{Np}, \mathrm{Pu}, \mathrm{Am}, \mathrm{Cm})$ in a nuclear facility or in the environment, internal contamination by either acute or chronic exposure has the potential to induce both radiological and chemical toxicities. Contrary to some heavy metals, actinides have no known essential role in the normal biochemical reactions occurring in living organisms, including plants, animals, and humans. Whatever the contamination route (inhalation, ingestion or wound), the radionuclide is absorbed, and then transported by blood (the absorption rate depends on the dissolution properties of the initial physico-chemical form) prior to deposition in the target organs (e.g. bone, kidney, and liver) in which it is stored and then slowly and partially excreted in the urine and faeces. These biological steps are dominated by kinetics and controlled by the thermodynamic equilibria of the radionuclide with biological ligands, highlighting the important role of speciation [1]. Actinides, like many exogenous metals, link with different biological ligands (proteins, amino acids, etc.) and might take the place of essential elements by analogy, but these phenomena are not always well known. Biokinetic models for actinides are rather well known and are described in detail in various publications of the International Commission on Radiological Protection (ICRP) [2-4] and the National Council on Radiation Protection and Measurements (NCRP) [5]. Nevertheless, those biokinetic models are more or less phenomenological and it would be of great importance to have a more detailed molecular understanding of them.

Consequently, the interactions of actinides with the various constituents of cells and tissues are important not only for a better understanding of the mechanisms controlling their specific tissue deposition pattern and the initiation of toxic effects, but also for the development of effective methods for treating persons who may become contaminated. In case of internal human actinide contamination, it is important to provide effective chelation therapy to reduce acute radiation damage, chemical toxicity, and late radiation effects.
Speciation analysis is thus a prerequisite tool, necessary for addressing the behaviour of cationic and anionic species within biological media, in order to understand better absorption and transport mechanisms in living organisms, distribution in organs or cells, and consequently bioavailability and toxicity. It may also yield significant input to decorporation [6] studies or treatment of the contamination, by providing guidance on the structure, affinity and design of potential specific chelating agents synthesized and used for the elimination of an incorporated radionuclide.

This review is aimed at presenting: $(i)$ the state of the art of decorporation studies; (ii) an outline on actinide metabolism, as known from the available experimental in vivo data; (iii) a review of the constraints for actinide decorporation, including some fundamental aspects of actinide solution chemistry, such as valence states, redox potentials, hydrolysis and complexation properties; (iv) what are the main tools developed and used for decorporation studies; $(v)$ a brief summary on existing chelating agents and what is known and missing about chelation of actinides with relevant biological molecules, including the problem with the interference and the balance of essential trace elements when using chelation therapy; and finally $(v i)$ what are the future trends in this field.

\section{State-of-the-art of decorporation treatments}

The potential hazards to human health of the nuclear materials, including actinides, activation and fission products, were recognized early, stimulating the search for effective ways to remove internally deposited radioelements from the body. Two major synthetic reviews, presented as guidebooks for decorporation of radionuclides from the human body have been published $[7,8]$. The main goal was to decrease the whole body content or a specific organ content in order to decrease the effective dose and so avoid deterministic and/or stochastic effects [6]. Nevertheless, the proposed or developed treatments should mainly vary as a function of the intake pathway throughout the organism, the level of contamination (mass and activity), the chemical and 
biological speciation, and should take into account the intervention time after the incident.

Table 1 reviews the different main treatments that have been developed and applied to decorporation taking into account the specific intake pathways and physico-chemical states of the actinides: (1) for contamination by inhalation, which is mainly concerned by aerosols that display different chemical solubilities, the proposed treatments aimed at increasing the solubility of the actinides deposited in the human respiratory tract and the mechanical removal along the respiratory tract via the gastro-intestinal tract, and finally at allowing a chelation of the absorbed fraction into the blood; (2) for contamination by ingestion, the developed treatments were mainly gastric dressing, precipitation, purge and chelation of the absorbed fraction into the blood; (3) for wound contamination, several treatments have been applied, including washing, surgical excision and dressings with additional specific chelating agent like gels, and chelation of the absorbed fraction into the blood.

These three different types of intake clearly show that therapeutic treatments should be adapted to the intake pathway, and also underline that, depending on different speciation of the actinides, blood is a common compartment before distribution in the organism.

\section{Actinide metabolism}

The biokinetics and bioinorganic chemistry of actinides following inhalation, ingestion and injection have been well studied in the past 50 years: models were reviewed and adopted in ICRP Publications 67 and 69 [3,4] and NCRP [5], discussed in Refs. [9-14] and currently revised by ICRP internal dosimetry

Table 1

Main treatments used in decorporation therapies versus the type of incorporation

\begin{tabular}{ll}
\hline Type of incorporation & Treatment \\
\hline Inhalation & $\begin{array}{l}\text { Lung washing } \\
\text { Blood chelation } \\
\text { (iv, ip, im) }\end{array}$ \\
Gastric dressing \\
Ingestion & Precipitation \\
& Purge \\
Wound & Washing \\
& Surgical excision, \\
& dressing \\
& Blood chelation \\
(iv, ip, im)
\end{tabular}

iv, Intravenous; ip, intraperitoneal; im, intramuscular.
(INDOS) working group. The main results summarized in Table 2 clearly show that actinides can be more or less absorbed into the blood (depending on their speciation) during a short transition time (10 min to $1 \mathrm{~h}$ ) before their distribution into target organs. It is also important to remember that only a small part of the actinides fixed in these target organs can recirculate in the blood. All these internal physico-chemical phenomena, which mainly correspond to absorption, retention (sorption, desorption) and excretion, are time dependent but also speciation dependent.

Within biological media, it is also important to note that plutonium and thorium are considered to be only present under An(IV) form, americium and curium under An(III) form, neptunium can be present under both forms $\mathrm{An}(\mathrm{IV})$ and $\mathrm{An}(\mathrm{V})$, and uranium under U(VI) form.

\subsection{Main actinides' biological ligands}

Most studies on actinide biokinetics focus on blood, since the overall behaviour of radionuclides is dependent on their residence time in this compartment. Several reviews [9-15] showed that most actinides, when present in blood, are mainly bound to the iron transport protein transferrin (Tf) [17], although the binding characteristics may vary from element to another. Tf appears to bind efficiently to $\mathrm{Pu}(\mathrm{IV}), \mathrm{Th}(\mathrm{IV})$ and $\mathrm{Np}$ (IV) (more than $80 \%$ of these actinides are complexed with Tf), whereas U(VI) is only moderately bound to Tf $(\sim 30 \%)$ (this actinide is also bounded to haemoglobin or red blood cells). Am(III) and $\mathrm{Np}(\mathrm{V})$ seem also to be weakly bound $(\sim 30 \%)$ to Tf. Am(III) is probably associated with other proteins (such as albumin) as the AmTf complex is not as stable as that of $\mathrm{Pu}[13,14,18]$.

Similar experiments have been performed on protein binding in tissue/organ deposition sites including liver, bone, and kidney. Several reviews $[13,14,19,20]$ present the possible transfer mechanisms of $\mathrm{Np}(\mathrm{V}), \mathrm{Pu}(\mathrm{IV})$ and Am(III) from blood to liver cells, and describe possible time- and mass-dependent binding of these actinides in the liver cells with high molecular weight proteins such as calmodulin, ferritin and lipofuscin. It has also been shown [21] that hepatocyte cells concentrate more plutonium than sinusoidal cells and that Kuppfer cells play an important role in the phagocytosis of polymeric forms of plutonium.

Investigations concerning bone deposition are rare but studies $[10,13]$ using mineralized bone or uncalcified matrix models for bone have, however, identified binding by proteins such as sialoproteins, chondroitin sulphate-protein complexes and glycoproteins as well as by transferrin. 
Table 2

Biokinetic data on actinides $[3,4,9-14]$

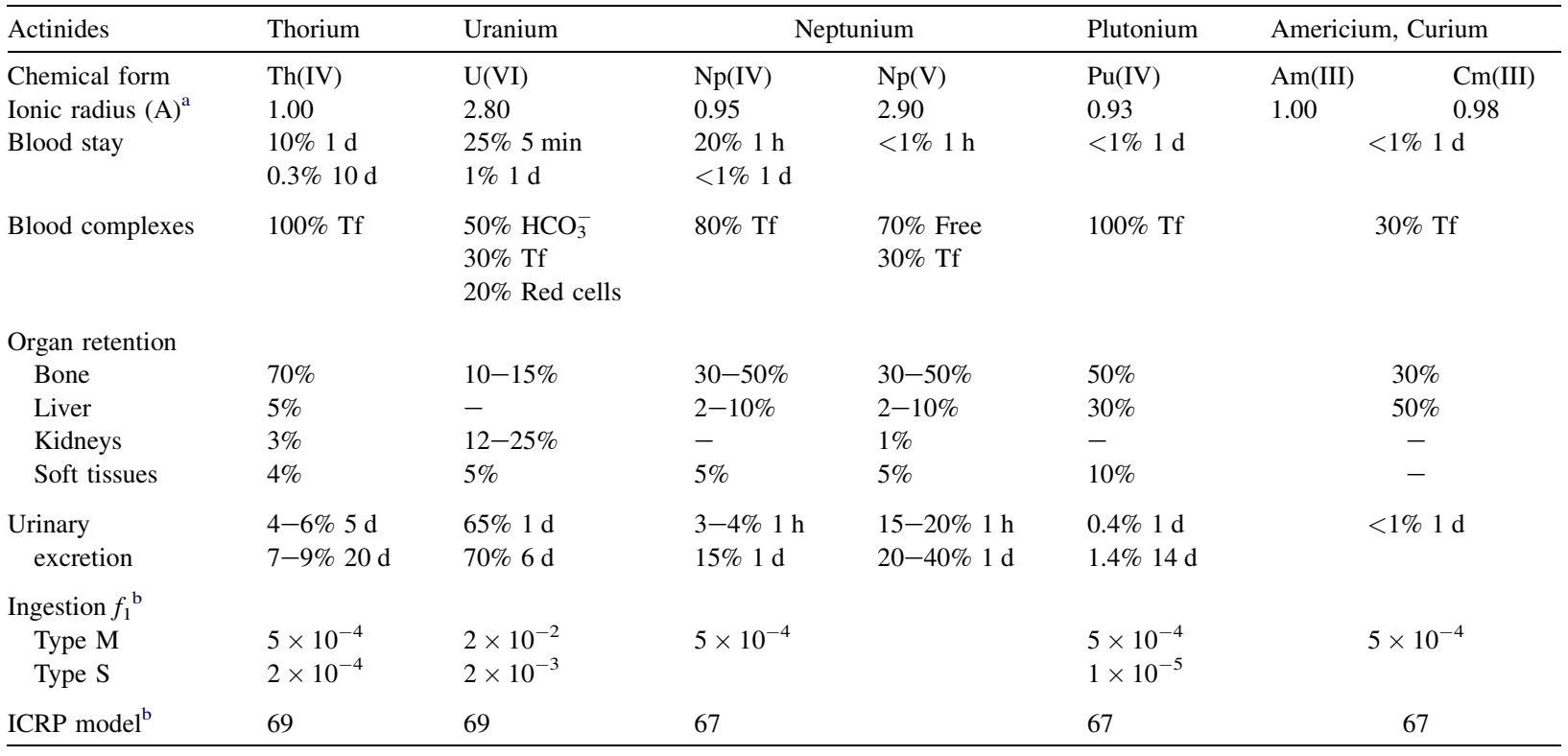

Tf, transferrin.

a Ionic radius: selected values between Goldschmidt, Pauling, Shannon and Marcus radii [16].

${ }^{\mathrm{b}} f_{1}$ is the fraction of an element entering the gastrointestinal tract which reaches blood [2-4]. Type M and Type S compounds are defined in ICRP models [2-4] as moderately (M) and slowly (S) absorbed compounds to blood.

\section{Constraints for actinide decorporation and some fundamental aspects of actinide solution chemistry}

The earliest efforts to remove actinides by means of dietary manipulation, supplements of hormones, or by scavenging through the use of common carboxylic acids or other complexing agents, or colloidal citrate were rather discouraging in terms of efficiency.

The methodological approach which was adopted by the scientific community from 1950 to 2000 was to develop chemical agents that would complex selectively actinides directly in the blood (which is the main pathway either by direct absorption or through recirculating absorption) and would form excretable low-molecular-weight chelates. Table 3 summarizes basic specifications [22] between actinides and potential chelating agents that should reflect some aspects of the solution chemistry of actinides and should be essential for clinical use. Some of these specifications have also been previously given for iron [23].

The sequestering agents should exhibit certain desirable qualities under physiological conditions. Hence

Table 3

Basic specifications between actinides and potential chelating agents

\begin{tabular}{|c|c|}
\hline Actinides & Ligands \\
\hline $\begin{array}{l}\text { Hard cations (Pearson) } \\
\text { Oxidation states } 3-6\left(\mathrm{Am}^{3+}, \mathrm{Np}^{4+}, \mathrm{NpO}_{2}^{+}, \mathrm{Pu}^{4+}, \mathrm{UO}_{2}{ }^{2+}\right) \\
\text { Hydrolysis ability } \mathrm{M}^{4+}>\mathrm{MO}_{2}{ }^{2+}>\mathrm{M}^{3+}>\mathrm{MO}_{2}{ }^{+} \\
\text {Redox (e.g. } \mathrm{Np}(\mathrm{IV}), \mathrm{Np}(\mathrm{V})) \\
\text { Numerous complexes }\left(\mathrm{OH}^{-}, \mathrm{H}_{2} \mathrm{PO}_{4}^{-}, \mathrm{HCO}_{3}^{-}\right) \\
\text {Dissociation constant kinetics of stable complexes are slow }\end{array}$ & $\begin{array}{l}\text { Donor atoms } \mathrm{O}>\mathrm{N}>\mathrm{S} \\
\text { Denticity or number of donor sites } \\
\text { Stereochemistry of ligand, size } \\
\text { Stability }(\mathrm{H} \text { bond) } \\
\text { Selectivity/(} \mathrm{Na}^{+}, \mathrm{Ca}^{2+} \text {, etc.) } \\
\text { Ionisation at physiological } \mathrm{pH} \\
\text { Hydrosoluble } \\
\text { Kinetic and thermodynamic } \\
\text { Ratio of ligand:metal ( }>1000: 1) \\
\text { Toxicity and FDA }\end{array}$ \\
\hline
\end{tabular}

FDA $=$ federal drug authorization 
several rules must be applied to any candidate ligand, such as those listed hereafter.

1. The chelating moieties of the ligand should be sufficiently deprotonated under physiological conditions to ensure efficient scavenging of the actinide of interest.

2. Ligands can be structurally classified according to the number of donor atoms (one donor atom corresponds to a monodentate, two to bidentate, and so on) that is involved in the metal coordination. The possibility for a polydentate ligand to coordinate depends both on the coordination geometry of the metal ion and on the steric constraints in the ligand. The number of chelate rings formed in the resultant ligand-metal complex is a factor of great importance in the stability of the complex: the more the rings, the greater the stability of the complex, and formation of complexes with a 1:1 stochiometry should be recommended. For example, an hexadentate ligand like EDTA can use all six donor atoms when coordinating $\mathrm{An}(\mathrm{III})$ or $\mathrm{An}(\mathrm{IV})$, but not in complexes with actinyl ions An(V) or An(VI).

3. Site(s) of action (e.g. blood, bone, kidney) of the sequestering agent need to be considered as this affects its physico-chemical properties for targeting. It has been shown that some actinide-ligand complexes could behave differently from the biological actinide complex: for example, uranium for which main target organ is kidney can be displaced to liver as a uranium-calixarene complex [8].

4. The agent should have high selectivity for actinides and low affinity for other biologically significant essential metal ions such as $\mathrm{Ca}(\mathrm{II}), \mathrm{Na}(\mathrm{I}), \mathrm{K}(\mathrm{I})$, $\mathrm{Fe}(\mathrm{II})$, and $\mathrm{Zn}(\mathrm{II})$. A good way to avoid such interferences is to use the ligand (e.g. DTPA) under different chemical forms such as $\mathrm{Na}_{3} \mathrm{CaDTPA}$ or $\mathrm{Na}_{3} \mathrm{ZnDTPA}$ [8].

5. Ligands of low toxicity are required: it has been observed that with the same basic chelating units, lowdenticity ligands were generally less toxic than those of high denticity, and linear ligands were less toxic than branched or cyclic ligands [23]. Nevertheless, there are some exceptions, like octadentate LIHOPO [18].

6. The bioavailability of the sequestering agent should be considered as should excretion pathways of the actinide-sequestering agent complex once it is formed in vivo; it is important to ensure that the agent is not metabolically degraded to metabolites and then unable to bind the metal. Ideally for maximal chelation, a chelator must be present within the extracellular fluids at both reasonable concentration $(10-25 \mu \mathrm{M})$ and duration to ensure interception of the actinide from either the intracellular or the extracellular pool.

7. The importance and desirability of lipophilic properties should be addressed.

8. High oral efficiency is very desirable for practical application and molecular mass is a critical factor which influences the rate of oral drug absorption: a "cut-off" molecular mass between 300 and $500 \mathrm{Da}$ for absorption by the human small intestine has been noticed [23].

9. Finally, for contamination incidents, the sequestering agent should have a federal drug authorization (FDA) and should be readily available at a low cost and very quickly.

On the other hand, the solution chemistry of actinides exhibits certain properties under physiological conditions such as those listed below.

1. Actinides are "hard" cations with a large ionic potential (charge-to-ionic-radius ratio: $z / r$ ) and therefore prefer "hard" oxygen and negatively charged oxygen donors. The bonding between cation and ligand is relatively well described by an electrostatic/ ionic model, where covalency is playing a minor role. Overall, they show a stronger preference for oxygen donor atoms and so interact preferentially with ligands containing such groups, rather than nitrogen, sulphur or phosphorous donors. Their ability to form complexes with inorganic ligands diminishes as follows: $\mathrm{PO}_{4}{ }^{3-}>\mathrm{CO}_{3}{ }^{2-}>\mathrm{OH}^{-}>\mathrm{SO}_{4}{ }^{2-}>\mathrm{Cl}^{-}$. At the same oxidation state, it is well known that the relative stability of the complexes with hard acids increases with the atomic number, due to the contraction of the actinide ionic radii.

2. The light actinide series (from $\mathrm{Th}$ to $\mathrm{Cm}$ ) corresponds to the filling of the $5 \mathrm{f}$ and $6 \mathrm{~d}$ electron shells and exhibits a range of oxidation states in aqueous media from + III to + VI [24-26]. The most stable redox states in acidic aqueous solution are $+\mathrm{IV}$ for plutonium and thorium, + VI for uranium, + IV and $+\mathrm{V}$ for neptunium, and + III for americium and curium $[25,26]$.

3. Actinide ions under + III and + IV forms have a coordination number of $8-12$, whereas $\mathrm{An}(\mathrm{V})$ and $\mathrm{An}(\mathrm{VI})$ have a coordination number of $6-8$ in the equatorial plane, and therefore have a tendency to form stable complexes with ligands of higher denticity.

4. Generally, for discussion of kinetic effects, the redox reactions of actinide species have been divided 
into two groups, namely those involving only electron transfer $\left(\mathrm{M}^{4+} / \mathrm{M}^{3+}\right.$ and $\mathrm{MO}_{2}{ }^{2+} / \mathrm{MO}_{2}{ }^{+}$pairs), for which reactions of simple electron exchange are fast, and those also requiring formation and/ or rupture of metal/oxygen bonds (e.g. $\mathrm{M}^{4+}$ / $\mathrm{MO}_{2}{ }^{+}$pairs), which tend to be kinetically slow.

5. A noteworthy aspect of actinide solution chemistry is the importance of hydrolysis reactions [25,26], which may be significant even in acidic media, such as:

$\mathrm{M}^{n}++m \mathrm{H}_{2} \mathrm{O} \leftrightarrow \mathrm{M}(\mathrm{OH})_{m}^{(n-m)+}+m \mathrm{H}^{+}$

The strength of hydrolysis follows the order $\mathrm{M}^{4+}>\mathrm{MO}_{2}{ }^{2+}>\mathrm{M}^{3+}>\mathrm{MO}_{2}{ }^{+}$. The $\mathrm{M}^{4+}$ and $\mathrm{MO}_{2}{ }^{2+}$ species are reported also to form very stable hydroxide oligomers (i.e. $\left[\mathrm{M}(\mathrm{OH})_{i}\right]_{n}$ ), depending on the actinide concentration. It is also important to mention that the transformation from hydroxide to hydrated oxide is non-reversible.

\section{Review of main tools developed and used for decorporation studies}

There are several analytical, experimental or modelling tools which can be used to perform decorporation studies and to test the efficiency of ligands toward actinide decorporation.

$>$ The first tool is the rational design and synthesis of ligands based on specification actinide-ligand, as described in Table 3. The most illustrative example concerns the similarities observed in the 1980s [27] between $\mathrm{Fe}$ (III) and actinides, especially Pu(IV), about their chemical and biological transport as well as their distribution properties [18,27]: they include ionic potential $(z / r)$ for $\mathrm{Fe}(\mathrm{III})$ and $\mathrm{Pu}(\mathrm{IV})$ (4.6 and 4.3, respectively), formation of highly insoluble hydroxides $\left(\mathrm{M}(\mathrm{OH})_{n}\right)$ and similar first-hydrolysis constants $\left(\mathrm{Pu}(\mathrm{OH})^{3+}\right.$ and $\left.\mathrm{Fe}(\mathrm{OH})^{2+}\right)$. This analogy allowed the development of all the compounds based on siderophore chemistry. A second example is the great chemical affinity between uranyl ion and phosphates and the current use of 1-hydroxyethane-1, $1^{\prime}$-diphosphonic acid (HEDP) (a simple phosphonate compound with the federal drug authorization (FDA)) in the medical treatment of bone disease: this association led several laboratories to develop and synthesize numerous promising polyphosphonate compounds [28-31]. The interaction between an actinide and a decorporating agent or a biological molecule can be determined typically by the use of analytical and speciation tools $[14,32]$, but also by the use of in vitro screening tests based on a displacement method with a reference chelating agent such as sulfochlorophenol $[28,33]$. These tools are very useful and allow one to test and select numerous compounds for their actinide-binding capabilities, before performing any in vivo experiments. In complement to this approach, molecular dynamics (MD) has also been developed in the last decades and successfully applied to determine structures and energy properties of biological macromolecules and proteins [14]. This in silico simulation approach can be used either at the design step or after in vitro or in vivo experiments. More recent studies have also highlighted the possibilities of using quantum chemistry calculations to investigate chemical reactions (bond breaks or formations), taking into account clusters (around 100 atoms) of these large molecular systems [35-39].

$>$ The second tool is the in vivo experiments on animals, which have been largely used and very well described in several recent reviews [8,13,34]. A recent report [40] made by a French collective working group and mobilized by the occupational medicine department presents a review of Ca-DTPA injections used for medical treatment of $\mathrm{Pu}$ and Am worker contamination in the CEA and COGEMA plants from 1970 to 2003. This report reviews data concerning 1158 injections administered to 469 persons and proposes posologies and therapeutic schemes following these observations on humans.

\section{Review of chelating agents developed and what is known and missing about chelation of actinides with relevant biological molecules}

This first approach has resulted in much research for new ligands [13,18,28-31] with higher affinity and selectivity for actinides and/or better lipophilicity to penetrate biomembranes.

Exhaustive reviews have recently been performed $[8,13,14,18,34]$ on the development of improved actinide-sequestering agents using lanthanide metal ions as suitable models as well as natural iron-chelating agents as a source of inspiration.

Among the different families of ligands synthesized, the main families of organic compounds that have been synthesized and tested for their in vivo decorporating efficiency on actinides since 50 years, are given in Table 4 .

They comprise:

(i) polyaminocarboxylic acids such as diethylenetriaminopentaacetic acid (DTPA) which is a reference 
Table 4

Main families of ligands efficient in terms of decorporation for actinides

\begin{tabular}{lll}
\hline Ligand family & Example of ligands & Elements \\
\hline Polyaminopolycarboxylics & (Ca,Zn,Na) DTPA & Pu(IV), Am(III) \\
Siderophores & LICAM (catechol) & Pu(IV), Am(III) \\
$\quad$ Basis: enterobactin) & LIHOPO (pyridinone) ${ }^{\mathrm{a}}$ & $\mathrm{Cm}(\mathrm{III}), \mathrm{Th}(\mathrm{IV}), \mathrm{U}(\mathrm{VI})$ \\
Macrocycles & Calixarens (toxic) & $\mathrm{U}(\mathrm{VI})$ \\
& Crown ether & $\mathrm{U}(\mathrm{VI}), \mathrm{Np}(\mathrm{IV})$ \\
Bisphosphonics & HEDP $^{\mathrm{a}}$ & $\mathrm{U}(\mathrm{VI})$ \\
Polyaminopolyphosphonates & CDTP $^{\mathrm{a}}$ & $\mathrm{U}(\mathrm{VI})$ \\
Polyphosphonates & tris-Bisphosphoniqes & \\
Various & Bicarbonates, Tiron & $\mathrm{U}(\mathrm{VI})$ \\
\hline
\end{tabular}

${ }^{\text {a }}$ Presented in Figs. 1 and 2.

ligand in decorporation and shown to be effective for plutonium and americium $[8,13,18,34]$;

(ii) natural siderophores such as ferrichrom, desferrioxamine (DFOM), and enterobactin (EB); multidentate catecholate and hydroxypiridonate ligands based on the EB model were then synthesized containing subunits such as catechol (CAM), sulfocatechol (CAM[S]), carboxycatechol (CAM[C]), catecholamide (TAM), and 1,2-hydroxypiridinone (1,2-HOPO) attached through amide linkage to linear (LI), cyclic (CY), aromatic (ME), or branched (TREN, H(2,2)) backbones that were tested in vivo and found to be mainly effective for uranium, plutonium, americium, curium and thorium $[8,13$, $18,34]$. Among these numerous compounds synthesized and tested, the two most famous are certainly 3,4,3-LI(1,2-HOPO) and 5-LIO(Me-3,2-HOPO) (Fig. 1);

(iii) macrocyclic compounds including cryptates, calixarenes and crown ether families that were potentially promising ligands but were found to be toxic $[8,34]$;

(iv) poly-phosphonates with the simplest basic compound, 1-hydroxyethane-1,1'-diphosphonic acid
(HEDP), found to be effective for uranium and neptunium, and also a large variety of other phosphonates under dipode or tripode forms that were found to tightly bind uranyl ion $[8,28-31,34]$ (Fig. 2);

(v) various other compounds that were not really effective, such as bicarbonate and 1,2-dihydroxy3,5-benzenedisulfonic acid (Tiron), and alginate $[8,34]$.

In parallel, the determination of thermodynamic equilibrium constants provides a quantitative measurement of the affinity of a particular ligand for actinide ions $[13,14]$. Some selected stability constants of actinides with selected ligands, such as DFOM, DTPA, EDTA, are given as examples in Table 5 and compared with some selected potential biological ligands. It is important to point out that these equilibrium constants refer to laboratory systems where the experimental conditions are such that only binary complexes are formed. In vivo, there are more potential ligands and one must not disregard the possible formation of ternary complexes. As the $\mathrm{pH}$ is sufficiently high, there may also be ternary Anligand-hydroxide complexes $[13,55]$.<smiles>O=C(NCCCN(CCCCN(CCCNC(=O)c1cccc(=O)n1O)C(=O)c1cccc(=O)n1O)C(=O)c1cccc(=O)n1O)c1cccc(=O)n1O</smiles>

3,4,3-LI(1,2-HOPO)<smiles>Cn1ccc(C(=O)NCCOCCNC(=O)c2ccn(C)c(=O)c2O)c(O)c1=O</smiles>

5-LIO(Me-3,2-HOPO)

Fig. 1. Examples of two efficient hydroxopyridonate compounds. 


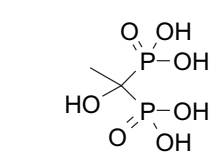

Diphosphonate (HEDP)

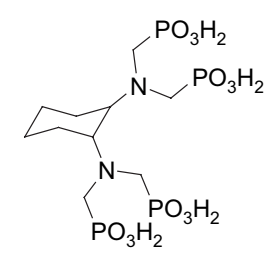

Tetraphosphonate (CDTP)

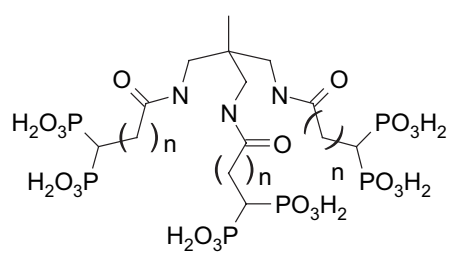

Tripode Bisphosphonate

Fig. 2. Examples of powerful ligands for uranium $\left(\mathrm{UO}_{2}{ }^{2+}\right)$ or lanthanides [28-31].

\section{The future trends of decorporation}

A second approach of decorporation, which is rather a pharmaceutical approach mainly developed with DTPA for plutonium, started from the experimental observation that the access to Pu by DTPA within the organ site was limited, due to the difficulty for DTPA to cross biological membranes. Liposomes, which are multilamellar vesicles and which can be encapsulated with a ligand such as DTPA, were extensively studied and evaluated in the 1970s, but came to an end after the late 1980s, despite promising results in animal studies. This pharmaceutical approach, also called vectorisation, is simpler since the main goals are to modify the pharmacokinetic disposition of DTPA in order to fit with the Pu traffic in vivo and to better penetrate biomembranes. As much progress has been made in liposome technology during the past two decades, this strategy was intensively revisited [56-58], and optimization of formulations led to polyethylene glycol-coated stealth liposomes around $100 \mathrm{~nm}$ decreasing the retention of $\mathrm{Pu}$ in the liver after 7 days by a factor 30 and increasing the excretion in the urine by a factor 10 compared to animals with no treatment.

This new approach clearly shows that decorporation can be achieved more efficiently by using optimized liposomal formulation of a ligand (e.g. DTPA) than by the usual free ligand treatment.

Future trends of decorporation should take into account basic specifications between actinides and ligands as summarized in Table 3. The design and synthesis of new higher performance ligands should still be encouraged but not considered only as a quest for the "Holy Grail" and should mainly focus on their formulation, which is essential for better access to the actinides as well as to any other metal in different biological compartments. An important issue that is often neglected due to the lack of information, and that should be seriously considered in the future is the role of the redox state within biological media (mainly enzymatic reactions), which is strongly related to oxygen and its free radicals (stress reactions) and iron chemistry. Thus the competition between Fe(III) and An(III) and An(IV) should certainly be the best illustration to explore. It is

Table 5

Stability constants of some biological and chemically relevant actinide complexes

\begin{tabular}{|c|c|c|c|c|c|c|c|}
\hline Actinides & Thorium & Uranium & Neptunium & & Plutonium & Americium & Curium \\
\hline Chemical form & $\operatorname{Th}(\mathrm{IV})$ & $\mathrm{U}(\mathrm{VI})$ & $\mathrm{Np}(\mathrm{IV})$ & $\mathrm{Np}(\mathrm{V})$ & $\mathrm{Pu}(\mathrm{IV})$ & Am(III) & $\mathrm{Cm}(\mathrm{III})$ \\
\hline \multicolumn{8}{|l|}{$\log K_{1}(I=0)$} \\
\hline Glycine $\left(\mathrm{L}^{-}\right)$ & $10.5^{\mathrm{b}}$ & $8.0^{\mathrm{b}}$ & & $3.3^{\mathrm{b}}(I=0.1)$ & & $4.1^{\mathrm{b}}(I=1)$ & \\
\hline Cysteine $\left(\mathrm{L}^{2-}\right)$ & $9.2^{\mathrm{b}}$ & $6.7^{\mathrm{b}}$ & & & & $4.2^{\mathrm{b}}(I=1)$ & \\
\hline Aspartate $\left(\mathrm{L}^{2-}\right)$ & $11.0^{\mathrm{b}}$ & $9.3^{\mathrm{b}}$ & & $2.6^{\mathrm{b}}(I=1)$ & & $6.1^{\mathrm{b}}$ & \\
\hline Glutamate $\left(\mathrm{L}^{2-}\right)$ & $10.8^{\mathrm{b}}$ & $9.2^{\mathrm{b}}$ & & $2.7^{\mathrm{b}}(I=1)$ & & $5.6^{\mathrm{b}}(I=1)$ & \\
\hline Lactate $\left(\mathrm{L}^{-}\right)$ & $5.7^{\mathrm{b}}$ & $2.9^{\mathrm{b}}$ & $2.1^{\mathrm{b}}$ & $2.1^{\mathrm{b}}$ & & $2.4^{\mathrm{b}}(I=1)$ & \\
\hline Citrate $\left(\mathrm{L}^{3-}\right)$ & $13.7^{\mathrm{a}}$ & $9.0^{\mathrm{a}}$ & $16.3[48]$ & $3.7^{\mathrm{a}}$ & $15.3^{\mathrm{a}}(I=0.5)$ & $8.6^{\mathrm{a}}$ & \\
\hline Transferrin & $20.4^{\mathrm{c}}$ & $16[51]$ & $24.7^{\mathrm{c}}[52]$ & $2.1^{\mathrm{c}}$ & $22.5[49,50]$ & $10.4^{\mathrm{c}}$ & $10.6^{\mathrm{c}}$ \\
\hline Desferrioxamine $\mathrm{L}^{3-}$ & $21.5^{\mathrm{b}}$ & & & & $30.8^{\mathrm{b}}$ & & \\
\hline Tiron $\left(\mathrm{L}^{4-}\right)$ & $21.1^{\mathrm{b}}$ & $17.5^{\mathrm{b}}$ & & & & & \\
\hline NTA $\left(\mathrm{L}^{3-}\right)$ & $19.5^{\mathrm{b}}$ & $10.8^{\mathrm{b}}$ & $17.3^{\mathrm{b}}(I=1)$ & $7.5^{\mathrm{b}}$ & & $13.9^{\mathrm{b}}$ & \\
\hline $\operatorname{EDTA}\left(\mathrm{L}^{4-}\right)$ & $26.6^{\mathrm{b}}$ & $13.7^{\mathrm{a}}$ & $31.2^{\mathrm{a}}$ & $9.3^{\mathrm{a}}$ & $26.4[53]$ & $19.7^{\mathrm{a}}$ & \\
\hline DTPA $\left(\mathrm{L}^{5-}\right)$ & $33.1^{\mathrm{b}}$ & $11.0^{\mathrm{b}}$ & $29.3^{\mathrm{b}}(I=0.5)$ & $11.7^{\mathrm{b}}$ & $29.5^{\mathrm{b}}(I=0.5)$ & $26.2^{\mathrm{b}}$ & \\
\hline
\end{tabular}

${ }^{\text {a }}$ Data from NEA, OECD, PSI [41-47].

b IUPAC database 2004 [54].

c Estimated by analogy [14]. Ionic strength correction ( $I$ ) was done when necessary using Davies' equation. Some constants are given with $I \geq 0.5$ which are indicative values whereas they cannot be used for calculation. 
also essential to keep in mind that chelation therapy can in some cases (e.g. An(III)) result in competition with the intracellular or extracellular balance, calcium balance ( $\mathrm{Ca}(\mathrm{II})$ has a very similar ionic radius as $\mathrm{An}(\mathrm{III})$ ions).

Finally, it is important to mention that in France, the "Commissariat à l' énergie atomique" (CEA), in association with three other French scientific research institutes, namely the "Centre national de la recherche scientifique" (CNRS), the "Institut national de la recherche agronomique" (INRA), and the "Institut national de la santé et de la recherché médicale" (INSERM), and supported by the "Ministère délégué à l'Enseignement et à la Recherche", initiated a programme of interdisciplinary research in 2004 called "Nuclear and Environmental Toxicology" (ToxNuc-E). Among the 15 projects treated in this programme, there are three projects that focus on actinides: one on decorporation, one on molecular targets, and one on biological chelation.

\section{References}

[1] D.M. Templeton, F. Ariese, R. Cornelis, L. Danielsson, H. Muntau, H.P. Van Leeuwen, R. Lobinski, Pure Appl. Chem. 72 (2000) 1453.

[2] International Commission on Radiological Protection, Individual Monitoring for Internal Exposure of Workers ICRP Publication 78, in: Annals of ICRP, vol. 27(3/4), Elsevier, Oxford, 1998.

[3] International Commission on Radiological Protection, Agedependent Doses to Members of the Public from Intake of Radionuclides: Part 2 ICRP Publication 67, in: Annals of ICRP, vol. 23 (3/4), Elsevier, Oxford, 1993.

[4] International Commission on Radiological Protection, Age-dependent Doses to Members of the Public from Intake of Radionuclides: Part 3, ICRP Publication 69, in: Annals of ICRP, vol. 25(1), Elsevier, Oxford, 1995.

[5] National Council on Radiation Protection and Measurements, Development of a biokinetic model for radionuclide-contaminated wounds and procedures for their assessment, dosimetry and treatment, NCRP Draft SC 57-17 Report, submitted for publication.

[6] D.R. Fisher, Health Phys. 78 (2000) 563.

[7] M.H. Bhattacharyya, B.D. Breitenstein, H. Métivier, B.A. Muggenburg, G.N. Stradling, V. Volf, G.B. Gerber (Eds.), Guidebook for the treatment of accidental internal contamination of workers, Radiat. Prot. Dosim. 41 (1992) 3.

[8] M.-H. Hengé-Napoli, G.N. Stradling, D.M. Taylor (Eds.), Decorporation of radionuclides from the human body, Radiat. Prot. Dosim. 87 (2000) 11.

[9] D.M. Taylor, J. Alloys Compd. 271 (1998) 6.

[10] J. Duffield, D.M. Taylor, The biochemistry of the actinides, in: A.J. Freeman, C. Keller (Eds.), Handbook on the Physics and Chemistry of the Actinides, Elsevier Science, 1991.

[11] P.W. Durbin, Health Phys. 8 (1962) 665.

[12] D.M. Taylor, Sci. Total Environ. 83 (1989) 217.

[13] P.W. Durbin, in: L.R. Morss, N.M. Edelstein, J. Fuger, J.J. Katz (Eds.), third ed., The Chemistry of the Actinide and Transactinide Elements, vol. 5, 2006 p. 3329.
[14] E. Ansoborlo, O. Prat, P. Moisy, C. Den Auwer, P. Guilbaud, M. Carrière, B. Gouget, J. Duffield, D. Doizi, T. Vercouter, C. Moulin, V. Moulin, Biochimie 88 (2006) 1605.

[15] J.D. van Horn, H. Huang, Coord. Chem. Rev. 250 (2006) 765.

[16] Y. Marcus, Ion Exchange and Solvent Extraction: Ion Properties, Marcel Dekker, Inc, New York, 1997, p. 43.

[17] H. Sun, H. Li, P.J. Sadler, Chem. Rev. 99 (1999) 2817.

[18] A.E.V. Gorden, J. Xu, K.N. Raymond, P. Durbin, Chem. Rev. 103 (2003) 4207.

[19] F. Paquet, S. Frelon, G. Cote, C. Madic, Radiat. Prot. Dosim. 105 (2003) 179.

[20] D.M. Taylor, A. Seidel, F. Planas-Bohne, U. Schuppler, M. Neu-Müller, R. Wirth, Inorg. Chim. Acta 140 (1987) 361.

[21] M. Fouillit, G. Grillon, P. Fritsch, G. Rateau, D. Pavé, J. Delforge, B. Le Gall, Int. J. Radiat. Biol. 80 (2004) 683.

[22] R.D. Hancock, A.E. Martell, Chem. Rev. 89 (1989) 1875.

[23] R.C. Hider, Biometals (2002) 751.

[24] G.T. Seaborg, Radiochim. Acta 61 (1993) 115.

[25] J.J. Katz, G.T. Seaborg, The Chemistry of the Actinide, Parts 1 and 2, Chapman and Hall, London, 1986.

[26] L.R. Morss, N.M. Edelstein, J. Fuger, J.J. Katz (Eds.), third ed. The Chemistry of the Actinide and Transactinide Elements, vol. 1-5, 2006.

[27] K.N. Raymond, W.L. Smith, F.L. Weitl, P.W. Durbin, E.S. Jones, K. Abu-Dari, S.R. Sofen, S.R. Cooper, in: N.M. Edelstein (Ed.), Lanthanide and Actinide Chemistry and Spectroscopy, 1980.

[28] M. Sawicki, J.-M. Siaugue, C. Jacopin, C. Moulin, T. Bailly, R. Burgada, S. Meunier, P. Baret, J.-L. Pierre, F. Taran, Chem. Eur. J. 11 (2005) 3689.

[29] R. Burgada, T. Bailly, M. Lecouvey, C.R. Chimie 7 (2004) 35.

[30] J. Gałezowska, R. Janicki, A. Mondry, R. Burgada, T. Bailly, M. Lecouvey, H. Kozłowski, Dalton Trans. (2006) 4384.

[31] H.-J. Cristau, D. Virieux, J.-L. Pirat, E. Ansoborlo, M.-H. Hengé-Napoli, F. Paquet, Phosphorus Sulfur Silicon Relat. Elem. 144 (1999) 505.

[32] Evaluation of speciation technology, AEN Workshop Proceedings Tokai-mura, Ibaraki, Japan, October 1999.

[33] O. Braun, C. Contino, M.-H. Hengé-Napoli, E. Ansoborlo, B. Pucci, Analusis 27 (1999) 65.

[34] G.N. Stradling, M.-H. Hengé-Napoli, F. Paquet, J.-L. Poncy, P. Fritsch, D. Taylor, Radiat. Prot. Dosim. 87 (2000) 19.

[35] M. Karplus, J.A. McCammon, Nat. Struct. Biol. 9 (2002) 646.

[36] L. Hemmingsen, P. Amara, E. Ansoborlo, M.J. Field, J. Phys. Chem. A 104 (2000) 4095.

[37] P. Guilbaud, G. Wipff, J. Phys. Chem. B 97 (1993) 5685.

[38] P.J. Hay, R.L. Martin, G. Schreckenbach, J. Phys. Chem. A 104 (2000) 6259.

[39] V. Vetere, B.O. Roos, P. Maldivi, C. Adamo, Chem. Phys. Lett. 396 (2004) 452.

[40] L. Grappin, P. Berard, P. Beau, L. Carbone, X. Castagnet, C. Courtay, J.-P. Le Goff, F. Ménétrier, M.-O. Neron, J. Piechowski, Actinides exposure: review of Ca-DTPA injections inside CEA-COGEMA plants. Report CEA-R-6097, 2006.

[41] I. Grenthe, J. Fuger, R. Lemire, R.J. Muller, C. Nguyen-Trung, H. Wanner, Chemical Thermodynamics of Uranium NEAOECD, Elsevier, Amsterdam, 1992.

[42] R. Lemire, J. Fuger, H. Nitsche, M.H. Rand, J. Rydberg, J. Sullivan, W. Ullman, P. Vitorge, K. Spahiu, H. Wanner, P. Potter, Chemical Thermodynamics of Neptunium and Plutonium NEA-OECD, Elsevier, Amsterdam, 2001. 
[43] R.J. Silva, G. Bidoglio, M.H. Rand, P.B. Robouch, H. Wanner, I. Puigdomenech, Chemical Thermodynamics of Americium, NEA-OECD, Elsevier, Amsterdam, 1995.

[44] R. Guillaumont, T. Fanghanel, J. Fuger, I. Grenthe, V. Neck, D.A. Palmer, M.H. Rand, Update on the Chemical Thermodynamics of $\mathrm{U}, \mathrm{Np}, \mathrm{Pu}, \mathrm{Am}$ and Tc, NEA-OECD, Elsevier, Amsterdam, 2003.

[45] W. Hummel, G. Anderegg, L. Rao, I. Puigdomenech, O. Tochiyama, Chemical Thermodynamics of Compounds and Complexes of U, Np, Pu, Am, Tc, Se, Ni and $\mathrm{Zr}$ with Selected Organic Ligands, NEA-OECD, Elsevier, Amsterdam, 2005.

[46] B. Allard, S.A. Banwart, J. Bruno, J.H. Ephraim, R. Grauer, I. Grenthe, J. Hadermann, W. Hummel, A. Jakob, T. Karapiperis, A.V. Plyasunov, I. Puigdomenech, J.A. Rard, S. Saxena, K. Spahiu, Modelling in Aquatic Chemistry, NEAOECD, Paris, 1997.

[47] W. Hummel, U. Berner, E. Curti, F.J. Pearson, T. Thoenen, Nagra/PSI Chemical Thermodynamics Data base 01/01, Universal Publishers, Parkland, Florida, 2002.

[48] L. Bonin, E. Ansoborlo, C. Den Auwer, G. Cote, P. Moisy, Radiochim. Acta, in press.
[49] J. Duffield, D.M. Taylor, Inorg. Chim. Acta 140 (1987) 365

[50] L.A. Yule, A comparison of the binding of plutonium and iron to transferrin and citrate, Thesis, University of Wales, Cardiff, UK, 1991.

[51] S. Scapolan, E. Ansoborlo, C. Moulin, C. Madic, Radiat. Prot. Dosim. 79 (1998) 505.

[52] R. Racine, P. Moisy, F. Paquet, H. Métivier, C. Madic, Radiochim. Acta 91 (2003) 115.

[53] H. Boukhalfa, S.D. Reilly, W.H. Smith, M.P. Neu, Inorg. Chem. 43 (2004) 5816

[54] IUPAC: International Union for Pure and Applied Chemistry. Stability constant database, http://www.acadsoft.co.uk 2004.

[55] M. Carrière, L. Avoscan, R. Collins, F. Carrot, E. Ansoborlo, B. Gouget, Chem. Res. Toxicol. 17 (2004) 446.

[56] G. Phan, B. Ramounet-Le Gall, J. Manceau, M. Fanet, H. Benech, P. Fritsch, E. Fattal, J.-R. Deverre, Int. J. Radiat. Biol. 80 (2004) 413.

[57] G. Phan, A. Herbet, S. Cholet, H. Benech, J.-R. Deverre, E. Fattal, J. Controlled Release 110 (2005) 177.

[58] G. Phan, B. Le Gall, G. Grillon, E. Rouit, M. Fouillit, H. Benech, E. Fattal, J.-R. Deverre, Biochimie 88 (2006) 1837. 